\title{
HABERLER
}

TÜRK DÜNYASI, Dil ve Edebiyat Dergisi/TURKISH WORLD, Journal of Language and Literature Issue: 43 (Bahar-Spring 2017) - ISSSN: 1301-0077 Ankara, TURKEY

DOI Numarası/DOI Number: 10.24155/tdk.2017.27

\section{ULUSLARARASI HOCA AHMED YESEVÎ VE GÜNÜMÜZDEKİ İZLERİ SEMPOZYUMU}

Nail TAN

3-18 Kasım 2015 tarihlerinde Paris'te düzenlenen UNESCO 38. Genel Konferansı'nda alınan karar üzerine 2016 yılı, T.C. Hükûmetinin teklifi ve Azerbaycan ile Kazakistan'in desteğiyle Hoca Ahmed Yesevî (1093-1166) ve Ord. Prof. Dr. M. Fuad Köprülü (1890-1966) Yılı ilan edilmişti. Köprülü, 1918 yılında yazdığı Türk Edebiyatında İlk Mutasavvıflar (1919) eserinde, Ahmed Yesevî'yi ilk defa bütün yönleriyle incelemiş, Anadolu dinî tasavvufi halk edebiyatına ve başta Bektaşilik olmak üzere tarikat kültürüne etkilerini ortaya koymuştu. 2016 yılında, böylece inceleyenle incelenen şahsiyet, mutlu bir tesadüf sonucu bir araya getirilmiş oldu.

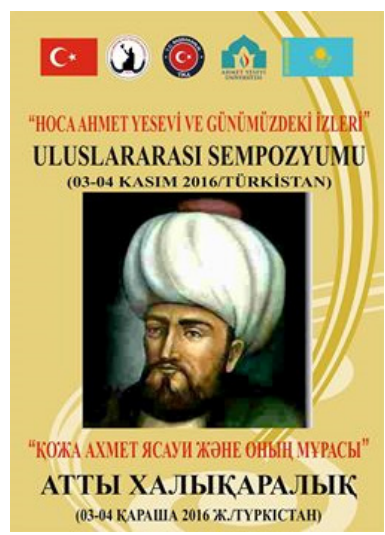

2016 y1lında Hoca Ahmed Yesevî’yle ilgili Türk dünyasında pek çok konferans, panel, sempozyum ve kongre düzenlendi. Son bilimsel toplantılardan biri, Kazakistan'ın eski Yesi, şimdi Türkistan şehrindeki Ahmet Yesevî Üniversitesinde 3-4 Kasım 2016 tarihleri arasında gerçekleştirildi.

"Hoca Ahmed Yesevî ve Günümüzdeki İzleri" konulu uluslararası sempozyum, T.C. Başbakanlık TİKA (Türk İşbirliği ve Kalkınma Ajansı)'nın maddi desteğiyle merkezi Hacıbektaş ilçesinde bulunan kamu yararına çalışan dernek statüsündeki Hacı Bektaş Velî Kültür Derneğince, Ahmet Yesevî Üniversitesi Rektörlüğü iş birliğiyle düzenlenmişti. Üniversite, Ankara'daki 
mütevelli heyeti vasıtasıyla yönetilmekte. 1990'lı yılların başında, güç şartlarda kurulmuş (1992) ama bugün 7.200 öğrencisiyle Türkistan şehrinde T.C.nin gurur kaynağı bir üniversite durumuna gelmiş. İki yöneticisi var: Kazakistanlı Rektör Prof. Dr. Valihan Abdibekov ve Türkiye'den Rektör Vekili Prof. Dr. Mehmet Kutalmış.

Sempozyum 3 Kasım 2016 Perşembe günü saat 10.30'da Üniversite Kültür Merkezinin muhteşem salonunda açılış töreniyle başlayacaktı. Tören öncesi, kayıt için merkezin ana kapısından girdiğimizde millî kıyafetler giymiş kız öğrenciler ve Kazak halk müziği topluluğunca karşılandık. Türkiye'den iki TİKA görevlisi (Hüseyin Ergezen, Zeynep Bayrak) dâhil 19 katılımcı, bu güzel karşılamadan çok hoşnut olduk. Aç1lış töreninde millî marşlardan sonra s1rasıyla Rektörler Prof. Dr. Valihan Abdibekov ve Prof. Dr. Mehmet Kutalmış, Hacı Bektaş Velî Kültür Derneği Genel Başkanı Mustafa Özcivan ile Dünya Söz Akademisi Başkanı Hayrettin İvgin birer konuşma yaparak sempozyumun düzenleniş amacını, konusunu, beklenen bilimsel katkıyı dile getirdiler. Protokol konuşmalarının ardından iki açılış bildirisi sunuldu:

Prof. Dr. Dosay Kenjetay: "Din Fenomolojisi Açısından Yesevilik Kültürünün İzleri”

Hayrettin İvgin: “Anadolu'daki Hoca Ahmed Yesevî Ocağı ve Âşık Teslim Abdal"

$\mathrm{Bu}$ bildirilerin ardından sempozyumun düzenlenmesinde hizmeti geçens lere plaket verildi. Katılımcılar, yanlarında getirdikleri kitapları üniversite kitaplığına konulmak üzere rektörlere teslim ettiler.

Öğle yemeğinden sonra bildirilerin sunulacağı oturumlara geçildi. Oturumlar tek salonda düzenlenmişti. Katılımcılar böylece birbirlerini dinleyip tartı̧̧malara katılma imkânına sahip oldular.

Türkiye'den 16, Kazakistan'dan da 8 bilim insanının katıldığı sempozyuł mun 3-4 Kasım 2016 günleri, beş oturumunda sunulan bildiriler sırasıyla şunlardir:

- Prof. Dr. Celâl Demir: "Hoca Ahmed Yesevî’nin Düşünce Dünyası"

- Prof. Dr. Zeki Kaymaz: “Divan-ı Hikmet’te Atasözleri ve Kullanılış Özellikleri”

- Doç. Dr. Bakytgul Kulzhanova: "Yusuf Has Hacip'in Düşüncelerinin Ahmet Yesevî’nin Tasavvuf İlmiyle Benzer Yönü”

- Osman Baş: "Hoca Ahmed Yesevî, Hayatı ve Eserleri"

- Zikiriya Zhandarbek: "Hoca Ahmed Yesevî, Hayatı ve Eserleri Hake kında"

- Nail Tan: "UNESCO 2016 Ahmed Yesevî ve Ord. Prof. Dr. M. Fuad Köprülü Yılı'nda Köprülü’nün Ahmed Yesevî’yle İlgili Çalışmaları” 
- Prof. Dr. Erdoğan Altınkaynak: "Hoca Ahmed Yesevî Hakkında An» latılanların Hacı Bektaş Velî’ye Aktarılması"

- Doç. Dr. Serjan Orazbay: "Hoca Ahmed Yesevî İlminin (Mirasının) Öğretim Sorunu"

- M. Sabri Koz: "Son Yayınlar Işı̆̆ında Evliya Çelebi Seyahatnamesi'nden Hoca Ahmed Yesevî Notları"

- Doç. Dr. Cupar Tanauova: "İslam Medeniyetinin Gelişmesi Yolunda Hoca Ahmed Yesevî’nin Rolü”

- Prof. Dr. Ali Yaman: "Günümüzde Yesevilik İzleri: Türkiye’de Alevi-Bektaşiler ve Kırgızistan'da Allahçılar"

- Yrd. Doç. Dr. Mehmet Yardımcı: "Yesevî Hikmetlerinin Anadolu Alevi Bektaşi Âşıkları Üzerindeki Etkileri"

- Aynur Abdirasilkızı: "Hoca Ahmed Yesevî Şairlik Okulu"

- Botagoz Abuova: "Hoca Ahmed Yesevî ve Edebiyat"

- Kaşımhan Deurenkulov: "Yesevilikte İnsan Sevgisi"

- Prof. Dr. Mehmet Ölmez: "Hikmetlerin Dili Kaçıncı Yüzyıla Aittir?"

- Doç. Dr. Elmira Adilbekova: "Türk Dilinin Meşhur Önderi Ahmed Yesevî ve Türkçe"

- Yrd. Doç. Dr. Ercan Ömirbayev: “Ötemiş Hacı'nın Cengiznamesi, Etnokültürel Bir Kaynaktır"

- Yrd. Doç. Dr. Vedi Aşkaroğlu: "Hoca Ahmed Yesevî ve Alevilikte Musahipliğin Sosyal Yapıdaki İzdüşümleri”"

- Necdet Kurt: "Yesevî Hikmetlerinden Anadolu Zâkirlik Geleneğine: Nasıl Oluştu? Etkileri ve Sonuçları"

- Kamber Özcivan: "Alevilik ve Bektaşilikte Hoca Ahmed Yesevî Düşüncelerinin Yeri ve Günümüzdeki İzleri”

- Doç. Dr. Mehmet Ali Yolcu: "Alevi Bektaşi İnanç Sisteminde Yeseviliğin İzleri”

- Gülağ Öz: "Hoca Ahmed Yesevî’nin Anadolu Ocakları Üzerindeki İzleri”

- Ali Yıldırım: "Hacı Bektaş Velayetnamesine Göre Hacı Bektaş-Ahmed Yesevî İlişkisi”"

- Nargiza Baltabeyeva: "Yesevî’nin Dünyaya Bakışı ve Günümüzde Yer Alan Dinî Bakışlar"

- Doç. Dr. Kımbat Rahmetovna Karatışkanova: "Hoca Ahmed Yesevî’nin Kazak Aydınlarına Etkisi”

Bildirilerin sunulup tartışılması tamamlandıktan sonra, 4 Kasım 2016 Cuma günü saat 16.00 'da Kapanış Oturumu için tekrar Kültür Merkezinin 


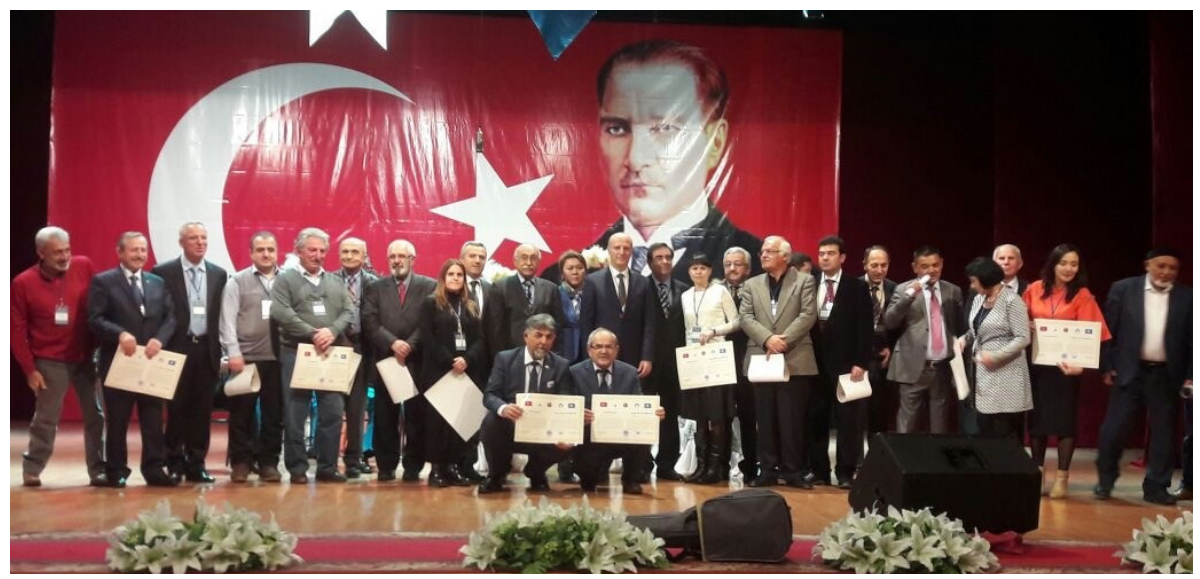

büyük salonunda toplanıldı. Öğrenciler ve öğretim üyeleri açılışta olduğu gibi salonu doldurmuşlardı. Rektör Yardımcısı Yrd. Doç. Dr. Mustafa Eren’in yönettiği bu oturumda Prof. Dr. Celal Demir, Hayrettin İvgin ve Mustafa Özcivan sempozyumu değerlendirdiler. Sunulan bildirilerde ileri sürülen yeni bilgi ve yorumlar üzerinde durdular. Hacı Bektaş Velî Kültür Derneği Genel Başkanı Mustafa Özcivan, düzenleyicilere ve katılımcılara teşekkür ederek bildirilerin en kısa zamanda yayımlanacağını belirtti. Katılım belgelerinin takdimi ve toplu fotoğraf çekiminden sonra sempozyumun bilim bölümü güzel bir konser ve halk oyunu gösterileriyle sona erdi.

5-6 Kasım 2016 Cumartesi ve Pazar günleri, sempozyumun kültürel gezilł er programı uygulandı. Üniversite Otelinin hemen yanı başında Hoca Ahmed Yesevî Parkı'nın ortasında Timur'un 1403-1405 yılları arasında yaptırmaya başladığı ancak tamamlayamadığı Hoca Ahmed Yesevî Türbesi ve Dergâh Külliyesi bulunuyordu. Türbe ve dergâhı, Türkistan'da otele yerleştiğimiz ilk gün 2 Kasım 2016 Çarşamba günü ziyaret edip gezmiştik. Ancak, bilinçli geziyi 5-6 Kasım 2016 tarihlerinde iki üç defa yaptık. Türbe, 1992-2000 yılları arasında T.C. Başbakanlık TIKKA tarafından büyük emek ve para harcanarak restore edilmiş, müze olarak düzenlenmişti. Yine TİKA tarafından çevresinde çok büyük bir park oluşturulmuştu. Sert iklim, bol suya rağmen çevresini yeterince ağaçlandırmaya izin vermemişti.

5 Kasım 2016 Cumartesi günü Türkistan yakınlarındaki Otrar şehrine gite tik. Timur, 1405 yılında Çin Seferi sırasında Otrar'da hayata gözlerini yummuş. Otrar'a giderken, bahar aylarında taşıp ovayı kaplayan Siriderya'nın kenarındaki yolu kullandık. Ovada deve, koyun, at sürüleri otluyordu. Otrar'a gitmemizin sebebi, Hoca Ahmed Yesevî’ye 16 y1l hocalık yapan Arslan Bab/ Baba’nın türbesinin, dergâhının bulunduğu şehir olmasıydı. Bu türbe ve dergâh da Timur tarafından yaptırılmış. Arslan Baba'nın türbesini ziyaret etme- 
den Hac1 Ahmed Yesevî Türbesini ziyaret hoş karşılanmıyor. Biz mecburen geleneğe uyamadık. Türbenin, dergâhın içi, dışı ve çevresi çok bakımlıydı. Ziyaretçisi de boldu.

Hoca Ahmed Yesevî'yi Türk dünyasında, Türkiye'de sevmeyen, saymayan yoktur denebilir. Horasan Erenleri vasitasıyla duygu ve düşünceleri, hikmetleri Anadolu'ya yayılmış, başta Yunus Emre olmak üzere pek çok tasavvuf şairinin yetişmesine yol açmıştır. Horasan eri/ereni Hacı Bektaş Velî’nin hocası Lokman Perende de Yesevî halifelerindendir. Yesevî'nin soyu, kızı Gevher Şahnaz ve kardeşi Hâce Sadreddin'den üremiş ve Anadolu'ya kadar ulaşmıştır. Ünlü gezgin Evliya Çelebi, seyahatnamesinde soyunun Hoca Ahmed Yesevî’ye dayandığını övünerek yazmıştır.

Sempozyum, ilk Türk tarikatı Yeseviliğin, Bektaşiliğe ve Anadolu ve Balkanlardaki dinî tasavvufi edebiyata etkilerini ortaya koyması bakımından yararlı sonuçlar ortaya koymuştur. Bildirilerin yayımlanmasıyla bu sonuçlar bilim dünyasının hizmetine sunulacaktır.

Ölümünün 850. yılında Hoca Ahmed Yesevî’yi saygıyla anarak onun Türkiye Türkçesine aktarılmış iki mısrasıyla yazımızı tamamlıyoruz. Mekânı cennet olsun!

Miskin, zaylf Hoca Ahmed, yedi atana rahmet

Fars dilini bilir de sevip söyler Türkçeyi

(Hayati Bice, Divan-ı Hikmet, Ankara, 1993, s. 93) 
